\title{
Anticonvulsant activity of Bacopa monniera in rodents
}

\author{
Darpan Kaushik ${ }^{1 *}$, Ashish Tripathi ${ }^{2}$, Rashmi Tripathi², \\ Madiwalayya Ganachari ${ }^{3}$, Suroor Ahmad Khan ${ }^{1}$
}

\author{
${ }^{I}$ F/O Pharmacy, Jamia Hamdard University, ${ }^{2}$ College of Pharmacy, Jakhrota, Agra, \\ ${ }^{3}$ Department of Pharmacology, KLE's College of Pharmacy
}

\begin{abstract}
Bacopa monnieri (L), belonging to the Scrophulariaceae family and commonly known as Brahmi, is well known in India for its CNS activity but its neuropharmacological effect has not yet been explored. In the present study, the antiepileptic effects of the plant were investigated. The ethanolic extract of Bacopa monniera was tested for anticonvulsant activity in albino rats, using different convulsive models. The ethanolic extract of leaves produced significant anticonvulsant activity for all the different models studied. The present study shows a probable mechanism of action similar to that of benzodiazepines (GABA agonist). Thus, these results emphasize the need to diversify by using alternative therapeutic approaches pertaining to herbal medicine, where a single easily available plant may provide solutions to several therapeutic challenges, as observed in the anticonvulsant action of ethanolic extract of $B$. monniera.
\end{abstract}

Uniterms: Bacopa monniera/pharmacognosy. Anticonvulsant. MES test. PTZ model. Hypoxia model. Strychnine model.

Bacopa monniera, da família Scrophulariaceae, e comumente denominada Brahmi, é bem conhecida na Índia por sua atividade no Sistema Nervoso Central, mas seu efeito neurofarmacológico não foi, ainda, explorado. No presente estudo, investigaram-se os efeitos antiepilépticos da planta. O extrato etanólico da Bacopa monniera foi testado quanto à atividade anticonvulsivante em ratos albinos, utilizando-se diferentes modelos de convulsão. $\mathrm{O}$ extrato etanólico das folhas produziu atividade anticonvulsivante significativa para todos os diferentes modelos estudados. O presente estudo mostra provável mecanismo de ação semelhante ao dos benzodiazepínicos (agonista do GABA). Assim sendo, esses resultados enfatizam a necessidade de diversificar, utilizando-se abordagens terapêuticas alternativas da medicina natural, em que uma planta facilmente disponível pode fornecer soluções para vários desafios terapêuticos, como o observado na ação anticonvulsivante do extrato etanólico de Bacopa monniera.

Unitermos: Bacopa monniera/farmacognosia. Anticonvulsivante. Teste MES. Modelo PTZ. Modelo hipóxia. Modelo estricnina.

\section{INTRODUCTION}

Bacopa monniera (Scrophulariaceae) is a small, creeping perennial herb, common in marshy places throughout India, and found up to an altitude of $1320 \mathrm{~m}$. The drug is present throughout the entire dried plant, but principally concentrated in leaves and stems (Handa et al., 1998). It has a wide range of CNS activity, but is most popularly considered a memory enhancer. Other pharmacological properties of the extracts include sedation (Kirtikar, Basu, 1999), cardiotonic (Kirtikar, Basu, 1999), vasoconstriction (Handa et al., 1998), anti-inflammatory activity (Viji, Helen, 2008) and astringency (Wealth of India, 1985). Juice

*Correspondence: D. Kaushik. F/O Pharmacy, Jamia Hamdard University, New Delhi-110062. e-mail: darpkaush@yahoo.com of the leaves relieves bronchitis and diarrhea (Wealth of India, 1985). A paste of the leaves is used as a remedy for rheumatism (Wealth of India, 1985). The entire plant is used in indigenous medicine as a nervous tonic (Chopra et al., 1956). Brahmighritha, a medicated ghee prepared from Bacopa monniera, is beneficial in cases of epilepsy and hysteria (Singh, Dhawan, 1997). Hersaponin, one of its active compounds, is reported to have a sedative effect (Malhotra, Das, 1959). It is also has laxative, carminative, digestive, purgative, emmenagogue, sudorific and antipyretic properties. It is useful in treating neuralgia, insanity, amentia, cancer, ulcers (Rao, Agarwal, 2000), dyspepsia, flatulence, asthma, skin diseases, leucoderma, syphilis, hoarseness, dysmenorrhea and sterility (Wealth of India, 1985). Additionally, it shows cardioprotective (Nandave et 
al., 2007) and hepatoprotective (Sumathi, Nongbri, 2008) effects. The plant is an aphrodisiac, effective in treating scabies and syphilis, and purifies the blood, having proven useful for diarrheas and pyresis (Kirtikar, Basu, 1999). The powdered dried leaf yielded satisfactory results in clinically tested cases of asthma, nervous breakdown and other low dynamic conditions (Singh, Dhawan, 1997). Bacopa monniera plant is known as a memory enhancer and act toward improving intellect (Handa, 1994). Although the plant is widely used for several ailments related to the central nervous system, its potential is unexplored. The present study was undertaken to investigate the anticonvulsant activity of an alcoholic extract of whole Bacopa monniera (BM), in different models of convulsion.

\section{MATERIAL AND METHODS}

\section{Plant materials}

The plant was collected in December 2000 from the outlying areas of Kolkatta City, West Bengal, India, and identified by staff of the KLE's RLS Institute, Dept. of Botany, Belgaum, Karnataka. The fresh leaves collected were shade dried and powdered.

\section{Preparation of Plant Extract}

Shade dried, powdered leaves were pounded until able to pass through sieve \# 20, with $60 \% \mathrm{v} / \mathrm{v}$ ethanol as solvent (Chaudhri, 1985). A total of 330 grams of dried leaves were soaked for 24 hours, whereupon upon the soaking solution was changed for three cycles of maceration. The percolate was concentrated in vacuum at $<50^{\circ} \mathrm{C}$ to give a semisolid extract (Sertia et al., 1997).

\section{Animals}

Wistar albino mice (18-25 g) and Wistar rats (150-200 g) of both sexes, purchased from the experimental animal house, Dept. of Livestock Production and Management, Veterinary College, Bangalore, were used. They were initially acclimatized to the laboratory environment for seven days prior to use. Institutional ethical committee approval of the experimental animal protocol was given for the present study.

\section{Drug Administration}

Bacopa monniera $(50 \mathrm{mg} / \mathrm{kg}$ and $55 \mathrm{mg} / \mathrm{kg}$ p.o. for rats and mice, respectively) was administered 2 and 4 hours before the respective convulsive stimuli. Diazepam
$4 \mathrm{mg} / \mathrm{kg}$, i.p (Ranbaxy, India), phenobarbitone $20 \mathrm{mg} / \mathrm{kg}$, i.p (Samarath Pharma ltd., India), adenosine $50 \mathrm{mg} / \mathrm{kg}$, i.p (Loba Chem., India) and theophylline $50 \mathrm{mg} / \mathrm{kg}$, i.p (SOL Pharma, India) were administered 45 minutes before the respective convulsive stimuli either alone or in combination with other drugs. Lithium chloride $3 \mathrm{meq} / \mathrm{kg}$, i.p (Loba Chem ltd., India) was administered 21 hours before pilocarpine $30 \mathrm{mg} / \mathrm{kg}$, sc (FDC, India) challenge. All drugs/chemicals used were dissolved in distilled water.

\section{METHODS}

\section{Motor Activity (Kulkarni, 1993)}

The mice were divided into two groups of six mice each. Mice were first individually placed in the photoactometer and normal movement recorded. After five minutes, the counter was stopped and the reading noted. The animal was then removed and the counter reset to zero. The same procedure was repeated for all animals.

Group 1 received $50 \mathrm{mg} / \mathrm{kg} \mathrm{BW}$ of extract orally. The animals were then individually placed in the photoactometer at $0.5,1,2,3,4$, and 5 hours and the readings were noted. The results were tabulated and converted into percentages for convenient calculations.

\section{Pentylenetetrazol-Induced Convulsions in Rats (Gupta et al., 1999)}

Albino rats of 150-200 $\mathrm{g}$ body weight were divided into five groups of six animals each. The first group, receiving saline orally, served as control whereas the second group received $4 \mathrm{mg} / \mathrm{kg}$ of diazepam intraperitoneally (ip); the third group received a sub protective dose of diazepam, i.e. $0.5 \mathrm{mg} / \mathrm{kg}$ i.p.; the fourth received $50 \mathrm{mg} / \mathrm{kg}$ of BM (po); and the fifth group received a sub protective dose of diazepam, i.e. $0.5 \mathrm{mg} / \mathrm{kg}$ and $50 \mathrm{mg} / \mathrm{kg}$ of BM. After an hour, all the animals were injected with $80 \mathrm{mg} / \mathrm{kg}$ pentylenetetrazol (Sigma, St. Louis, USA) intraperitoneally and presence or absence of clonic convulsions was noted for each animal.

The $\%$ latencies of clonic convulsions were noted, and numerically transformed to a seizure score (S) calculated from the formula:

$\mathrm{S}=1$ - (control Latency/ drug seizure Latency)

In the case of control animal; $\mathrm{S}=0$, whereas for animals that did not experience seizures latencies of infinity, $\mathrm{S}=1$. This numerical transformation enabled inclusion 
of all animals in the statistical analysis, irrespective of whether they had a seizure or not. The mortality in the $24 \mathrm{~h}$ following PTZ, in the different pretreatment groups was also recorded.

\section{Maximal Electroshock (MES) - Induced Convulsion in Rats (Rana et al., 1990)}

Albino rats of 150-200 g body weight were divided into three groups of six animals each. The first group, which received saline orally, served as the control whilst the second group received $30 \mathrm{mg} / \mathrm{kg}$ of phenobarbitone sodium intraperitoneal (ip), and third group received $50 \mathrm{mg} / \mathrm{kg}$ of BM (po). After an hour of treatment, convulsions were produced in rats using an "Inco" convulsiometer by delivering current of $150 \mathrm{~mA}$ through corneal electrodes for a period of 0.2 seconds. The severity of convulsions was assessed by the duration of flexion, extension, clonus, stupor and recovery phase for each animal. Inhibition of extensor phase was studied in this model.

\section{Strychnine-Induced Convulsion in Rats (Kulkarni, Pasty, 1998)}

Eighteen albino rats each weighing 150-200 g were divided into three groups of six rats each. The first group received saline orally and served as the control, while the second received $4 \mathrm{mg} / \mathrm{kg}$ of diazepam (ip), and third group received $50 \mathrm{mg} / \mathrm{kg}$ of BM orally. After an hour of treatment, $4 \mathrm{mg} / \mathrm{kg}$ of strychnine $(\mathrm{CDH}$, Bombay) was administered intra peritoneally to control and drug treated animals, which produced powerful opisthotonus tonic convulsions of the body and limbs. The latency of convulsions and the $\%$ mortality was assessed for each animal.

\section{Hypoxic Stress-Induced Convulsions in Mice (Kulkarni, Pasty, 1998)}

The albino mice each weighing 18-25 g, were divided into seven groups of six mice each. Group one was given saline orally and served as the control; group two received $4 \mathrm{mg} / \mathrm{kg}$ of diazepam (ip), group three received $50 \mathrm{mg} / \mathrm{kg} \mathrm{BM}$ orally, group four received $50 \mathrm{mg} / \mathrm{kg}$ adenosine (ip), group five received $50 \mathrm{mg} / \mathrm{kg}$ of theophylline (ip), group six received $50 \mathrm{mg} / \mathrm{kg}$ of BM orally followed by $50 \mathrm{mg} / \mathrm{kg}$ of adenosine (ip), and group seven received $50 \mathrm{mg} / \mathrm{kg}$ of BM orally followed by $50 \mathrm{mg} / \mathrm{kg}$ of theophylline (ip). The mice were put individually into a glass container of $370 \mathrm{~mL}$ capacity for induction of convulsion. The container was air tight, so under these circumstances, the animal showed convulsions and then mortality due to hypoxia. The latency for convulsions and death was assessed for each animal.

\section{Lithium-Pilocarpine-Induced Status Epilepticus (Kulkarni et al., 1998)}

Eighteen albino rats each weighing between 150-200 g were divided into three groups of six rats each. The first control group received saline orally; the second group received $4 \mathrm{mg} / \mathrm{kg}$ of diazepam (ip), and third group received $50 \mathrm{mg} / \mathrm{kg}$ of BM orally. Status epilepticus was induced by intra peritoneal injection of $3 \mathrm{meq} / \mathrm{kg}$, (ip) lithium chloride, followed by $30 \mathrm{mg} / \mathrm{kg}$, (sc) pilocarpine $21 \mathrm{~h}$ later. The animals were observed for a period 90 minutes for behavioral seizures. Immobility, repetitive chewing, head nodding, vibrissial twitching, forelimb clonus with or without rearing and falling, characterized behavioral seizures evoked by $\mathrm{LiCl} /$ pilocarpine. Seizure terminations were defined as the absence of forelimb clonus or falling, facial twitching and stop and stare activity. The onset was taken as the time of onset of forelimb clonus with rearing $(\mathrm{FC}+\mathrm{R})$. The extract was administered 2 hours prior to pilocarpine challenge, while diazepam was administered 30 minutes prior to pilocarpine challenge.

\section{Statistical Analysis and Calculations}

The $\%$ inhibition (or decrement) was calculated by using the formula:

$\%$ inhibition $=(1$-test reading $/$ Control reading $) \times 100$ Student's t- test was performed for statistical analysis. $\mathrm{P}<0.05$ was considered statistically significant.

\section{RESULT AND DISCUSSION}

BM extract showed a broad spectrum of anticonvulsant profile against chemical, electrical and hypoxic convulsions.

\section{Motor Activity}

The dose of BM i.e. $50 \mathrm{mg} / \mathrm{kg}$ BW po, produced a decrease in loco motor activity starting 30 minutes after administration and lasting until the $5^{\text {th }}$ hour. The peak decrease in motor activity was seen at the $5^{\text {th }}$ hour $(20.90 \% \pm 3.17)$, compared to the baseline reading at 0 hour (Table I). Bacopa monniera elicited its peak CNS depressant activity at the $5^{\text {th }}$ hour in mice. This also indicated the election of the $5^{\text {th }}$ hour, after administration of the extract, as the time to induce convulsions in mice. 
TABLE I - Assessment of loco motor activity using a photoactometer

\begin{tabular}{lccccccc}
\hline Group & Treatment & \multicolumn{5}{c}{ Percentage decrease of locomotor activity } \\
& $(\mathrm{mg} / \mathrm{kg})$ & $30 \mathrm{~min}$ & $1 \mathrm{hr}$ & $2 \mathrm{hr}$ & $3 \mathrm{hr}$ & $4 \mathrm{hr}$ & $5 \mathrm{hr}$ \\
\hline 1 & $\mathrm{BM}(50)$ & $65.40 \pm 1.48$ & $81.04 \pm 1.82$ & $63.74 \pm 4.51$ & $36.70 \pm 2.68$ & $34.83 \pm 2.58$ & $20.90 \pm 3.17$ \\
\hline
\end{tabular}

\section{Effect on Pentylenetetrazol-Induced Convulsions}

Diazepam at $4 \mathrm{mg} / \mathrm{kg}$ BW i.p protected the animals from PTZ-induced convulsions with no clonic convulsions occurring within the period of observation. However, at a sub- protective dose of $0.5 \mathrm{mg} / \mathrm{kg} \mathrm{BW}$ i.p, clonic convulsions occurred giving rise to a mean score (S) of $0.60 \pm 0.01$. BM at $50 \mathrm{mg} / \mathrm{kg}$ orally, gave $40 \%$ protection with a mean score for PTZ-induced convulsions of $\mathrm{S}=$ $0.40 \pm 0.01$ (Table II). Combinations of the sub-protective dose of diazepam, $0.5 \mathrm{mg} / \mathrm{kg}$ i.p. and BM $50 \mathrm{mg} / \mathrm{kg} \mathrm{BW}$. po fully protected the animals from clonic convulsions with $0 \%$ mortality.

The probable protection in this model (Rho \& Raman, 1999) is mediated either by:

1) Suppression of $\mathrm{Ca}^{2+}$ conductance across low threshold T- type Channels, or

2) Enhancement of $\mathrm{GABA}_{\mathrm{A}}$ receptor mediated $\mathrm{Cl}^{-}$conductance.

TABLE II - Pentylenetetrazole-Induced convulsions in rats

\begin{tabular}{lcc}
\hline Treatment $(\mathrm{mg} / \mathrm{kg})$ & $\begin{array}{c}\text { Mean score } \\
(\text { Mean } \pm \text { SEM })\end{array}$ & \% Mortality \\
\hline Control & $0 \pm 0.00$ & 100 \\
Diazepam(4) & $1 \pm 0.00 * * * *$ & 0 \\
Diazepam $(0.5)$ & $0.60 \pm 0.01 * * * *$ & 0 \\
BM $(50)$ & $0.40 \pm 0.01 * *$ & 83.33 \\
BM $(50)+$ Diazepam $(0.5)$ & $0.63 \pm 0.01 * *$ & 0 \\
\hline $\mathrm{N}=6, * * \mathrm{p}<0.02, * * * * \mathrm{p}<0.001$ (compared to control)
\end{tabular}

BM can lower the dose of diazepam that is required for protection against seizures. This may indicate a GABAergic mechanism as the effect of diazepam was potentiated and similar to a full protective dose of diazepam (4 mg/kg BW, ip). This model reveals that BM may be clinically effective against generalized-spike-wave absence epilepsies (Rho, Raman, 1999).

\section{Effect on Maximal Electro-shock-Induced Convulsion}

$\mathrm{BM}$ at $50 \mathrm{mg} / \mathrm{kg} \mathrm{BW}$ po produced a more significant effect $(\mathrm{P}<0.001)$ in the phases of extension, $5.63 \pm 0.49$ minute and recovery $43.56 \pm 2.37(\mathrm{P}<0.01)$ compared to controls $9.0 \pm 0.48$ and $72.16 \pm 4.37$ minutes, respectively (Table III). The dose of BM did not stop hind limb extension, but decreased it by nearly half the extension time in controls. This indicates its ability to prevent the spread of seizure in the central nervous system (Rho, Raman, 1999).

The MES model has served to identify antiepileptic drugs that are functionally similar to phenytoin and most of these compounds display, the same ability to inactivate voltage dependent $\mathrm{Na}^{+}$channels in a use dependent fashion. Such compounds have been shown to suppress sustained repetitive firing in cultured neurons (Rho, Raman, 1999).

Thus, BM is expected to have a similar type of mechanism, and may be effective against partial and secondary generalized seizures.

\section{Effect on Strychnine-Induced Convulsion}

$\mathrm{BM}$ at $50 \mathrm{mg} / \mathrm{kg} \mathrm{BW}$ po caused a significant

TABLE III - Maximal Electroshock-Induced convulsions in rats

\begin{tabular}{lccccc}
\hline $\begin{array}{l}\text { Treatment } \\
(\mathrm{mg} / \mathrm{kg})\end{array}$ & Flexion & Extension & Clonus & Stupor & Recovery \\
\hline $\begin{array}{l}\text { Control } \\
\text { Phenobarbitone }\end{array}$ & $1.46 \pm 0.18$ & $9.0 \pm 0.48$ & $9.68 \pm 0.57$ & $52.01 \pm 4.00$ & $72.16 \pm 4.37$ \\
Sodium $(30)$ & $5.23 \pm 0.04 * * *$ & $0.00 \pm 0.00^{* * * *}$ Nil & $9.16 \pm 0.04$ & $17.61 \pm 0.24 * *$ & $32.35 \pm 0.40^{* * * *}$ \\
BM $(50)$ & $2.4 \pm 0.58$ & $5.63 \pm 0.49^{* * * *}$ & $7.66 \pm 1.29$ & $32.86 \pm 1.93$ & $43.56 \pm 2.37^{* * * *}$ \\
\hline $\mathrm{N}=6, * *$
\end{tabular}

$\mathrm{N}=6,{ }^{*} \mathrm{p}<0.01, * * * \mathrm{p}<0.01, * * * * \mathrm{p}<0.001$ (compared to control) 
$(\mathrm{P}<0.01)$ delay in the onset of convulsion, $25.57 \pm 0.25$ minutes. It gave very good protection compared to the control (Table IV), whereas the diazepam-treated group had $0 \%$ mortality and no convulsions. BM significantly increased the onset time of the convulsion in this model. It is known that strychnine's lethal convulsant action is a result of glycine antagonism in the spinal cord. Thus, the probable mechanism may be diazepam-like, displacing strychnine from the receptor site (Nogardy, 1998). Thus, BM may be clinically effective in simple partial seizures.

TABLE IV - Strychnine-Induced convulsions in rats

\begin{tabular}{lcc}
\hline $\begin{array}{l}\text { Treatment } \\
(\mathrm{mg} / \mathrm{Kg})\end{array}$ & $\begin{array}{c}\text { Onset of convulsions } \\
(\mathrm{Min} \pm \mathrm{SEM})\end{array}$ & $\%$ Mortality \\
\hline Control & $1.66 \pm 0.01$ & 100 \\
Diazepam(4) & $0.0 \pm 0.00^{* * *} \mathrm{Nil}$ & 0 \\
$\mathrm{BM}(50)$ & $25.57 \pm 0.25^{* * *}$ & 50 \\
\hline
\end{tabular}

$\mathrm{N}=6, * * * \mathrm{p}<0.01$ (compared to control)

\section{Effect on Hypoxia Stress-Induced Convulsion}

Slow induction of hypoxic stress in mice resulted in increased respiratory rate, tremors and convulsions followed by death. Marked urination and defecation were also observed. Control animals developed convulsions within $46.25 \pm 0.14 \mathrm{~min}$ and died within $47.07 \pm 0.02$ minutes. Diazepam at $4 \mathrm{mg} / \mathrm{kg} \mathrm{BW}$ ip, halted the convulsions and significantly $(\mathrm{P}<0.01)$ prolonged the death time to $58.57 \pm 0.007$ compared to controls. $\mathrm{BM}$ at a dose of $55 \mathrm{mg} / \mathrm{kg}$ BW po, produced a significant delay in $(\mathrm{P}<0.01)$ the onset of convulsions, to $61.54 \pm 0.09$ minutes, and an extended death time of $62.32 \pm 0.03$ minutes (Table V). Pretreatment with adenosine $50 \mathrm{mg} / \mathrm{kg} \mathrm{BW}$ ip produced latency of convulsions, $56.97 \pm 0.24$ minutes, where this was statistically significant $(\mathrm{P}<0.02)$ compared to control. The difference in death time of control and adenosine group, $57.60 \pm 0.15$ minutes, was also significant. Initial treatment with BM ( $55 \mathrm{mg} / \mathrm{kg} \mathrm{BW}$ po), followed three hours and fifteen minutes later by adenosine, $(50 \mathrm{mg} / \mathrm{kg}$ BW ip), caused a significant increase $(\mathrm{P}<0.001)$ in latency of convulsions, $66.44 \pm 0.52$ minutes. Treatment of mice with theophylline $(50 \mathrm{mg} / \mathrm{kg}$ bw ip) caused significantly earlier onset $(\mathrm{P}<0.01)$ of convulsions at $36.01 \pm 0.15 \mathrm{mi}-$ nutes, and death time at $36.94 \pm 0.23$ minutes, compared to controls. After pretreatment with BM, (55 mg/kg bw ip) the decrease in the onset of convulsion and death time was reduced to $41.27 \pm 0.01$ and $41.91 \pm 0.21$ minutes, respectively, compared to the control group, reaching statistical significance $(\mathrm{P}<0.02)$.

The physiological changes following acute hypoxia stress, such as convulsion and death, are mainly due to cerebral hypoxia. BM showed a significant protective effect which appears to be centrally mediated. Whether the delay in the onset of convulsions was due to BM anticonvulsant properties or to inhibition of sympathetic discharge is unclear. (Kunchandy, Kulkarni, 1998).

\section{Effect on Lithium Pilocarpine-Induced Status Epilepticus}

Treatment with BM $(50 \mathrm{mg} / \mathrm{kg}$ po $)$ two hours before pilocarpine challenge produced a significant increase $(\mathrm{P}<0.05)$ in the onset of convulsion, measured as $29.33 \pm 2.45$ minutes (Table VI).

The ability of BM at a dose of $50 \mathrm{mg} / \mathrm{kg} \mathrm{BW}$ po to delay the onset of convulsion in this model, demonstrated its ability to counteract the underlying pathophysiology.

The factors that influence the beginning and end point of status epilepticus are unknown but a role has been proposed for both glutamate mediated excitation and lack of GABA mediated inhibition (Vadillo, Noya, 1997). The seizure evolves from cholinergic hyperactivity to full blown clonic seizures occurring repeatedly. These seizures are aborted by diazepam and other diazepam-like drugs.

TABLE V - Hypoxic Stress-Induced convulsions in rats

\begin{tabular}{lcc}
\hline Treatment $(\mathrm{mg} / \mathrm{kg})$ & Onset of convulsion $($ Min \pm SEM) & Death Time ( Min \pm SEM) \\
\hline Control & $46.25 \pm 0.14$ & $47.07 \pm 0.02$ \\
Diazepam & $0.00 \pm 0.00^{* * *}$ & $58.57 \pm 0.007^{* * *}$ \\
BM(50) & $61.54 \pm 0.09^{* * *}$ & $62.32 \pm 0.03^{* * *}$ \\
Adenosine (50) & $56.97 \pm 0.24^{* *}$ & $57.60 \pm 0.15^{* * *}$ \\
Theophylline (50) & $36.01 \pm 0.15^{* *}$ & $36.94 \pm 0.23^{* * *}$ \\
Adenosine (50) + BM (50) & $66.44 \pm 0.52^{* * * *}$ & $67.40 \pm 0.52^{* * *}$ \\
Theophylline (50) + BM (50) & $41.27 \pm 0.01^{* *}$ & $41.31 \pm 0.21^{* *}$ \\
\hline
\end{tabular}

$\mathrm{N}=6, * * \mathrm{p}<0.01, * * * \mathrm{p}<0.01, * * * * \mathrm{p}<0.001$ (compared to control) 
TABLE VI - Lithium -Pilocarpine-Induced status epilepticus in rats

\begin{tabular}{lcc}
\hline Treatment $(\mathrm{mg} / \mathrm{kg})$ & $\begin{array}{c}\text { Onset of Convulsions } \\
(\mathrm{FC}+\mathrm{R})(\mathrm{Min} \pm \mathrm{SEM})\end{array}$ & \% Mortality \\
\hline Control & $21.33 \pm 1.28$ & 100 \\
$(\mathrm{Li}+$ Pilocarpine $)$ & $90.5 \pm 1.56^{* *}$ & 0 \\
Diazepam (4) & $29.33 \pm 2.45^{*}$ & 83.33 \\
\hline $\mathrm{BM}(50)$ &
\end{tabular}

$\mathrm{N}=6, * \mathrm{p}<0.05, * * \mathrm{p}<0.02$ (compared to control)

Thus, BM may act based on the same mechanism as BDZ, i.e. through a GABAergic mechanism. This model may validate some aspects of psychomotor or temporal lobe epilepsy (Gupta et al., 1999).

\section{CONCLUSION}

The present study shows that the alcoholic extract of Bacopa monniera may function in a similar manner to BZD, given its benzodiazepine-like action, although the specific receptor interactions were not evaluated. Further evaluation of Bacopa monniera is needed to establish its exact mechanism of action. However, we conclude that the alcoholic extract of Bacopa monniera is a potent anticonvulsant drug.

\section{ACKNOWLEDGEMENTS}

The authors would like to thank the Principal of the KLE's College of Pharmacy, Belgaum, for kindly providing the necessary facilities for this project.

\section{REFERENCES}

CHOPRA, R. N.; NAYAR, S. L.; CHOPRA, I. C. Glossary of Indian medicinal plants. New Delhi: CSIR, 1956. p.32.

CHAUDHRI, R. D. Herbal drug industry: a practical approach to industrial pharmacognosy. New Delhi: Eastern Publishers, 1985. 589 p.

GUPTA, Y. K.; MALHOTRA, J.; GEORGE, B.; KULKARNI, S. $\mathrm{K}$. Methods and consideration for experimental evaluation of antiepileptic drugs. Indian J. Physiol. Pharmacol., v.43, n.1, p.25-43, 1999.

HANDA, S. S. Rasaayana drugs: part-II. Pharma Times, v.26, n.3, p.17-25, 1994.
HANDA, S. S.; DEEPAK, M.; MANGAL, A. K. Indian herbal pharmacopoeia. Jammu: IDMA, Mumbai \& RRL, 1998. v.1, p.30-37.

KRITIKAR, K. R.; BASU, B. D. Indian medicinal plants. Dehradun: Book Sellers \& Publisher, 1999. v.3, p.18151817.

KULKARNI, S. K. Handbook of experimental pharmacology. 2.ed. Delhi: Vallabh Prakashan, 1993. p.43-45.

KULKARNI, S. K.; PASTY, J. Anticonvulsant profile of Siotone granules, a herbal preparation. Indian J. Expt. Biol., v.36, n.7, p.658-662, 1998.

KULKARNI, S. K.; GEORGE, B.; MATHUR, R. Neuroprotection by Withania sommifera root extract against lithium pilocarpine induced seizures. Indian Drugs, v.35, n.4, p.208-216, 1998.

KUNCHANDY, J.; KULKARNI, S. K. Hypoxic stress induced convulsion and death: protective effect of $\alpha 2$-adrenoceptor and benzodiazepine receptor against Ro5-4864. Arch. Int. Pharacodyn., v.292, n.2, p.35-44, 1998.

MALHOTRA, C. L.; DAS, P. K. Pharmacological studies of Herpestis monniera Linn (Brahmi). Indian J. Med. Res., v.47, n.3, p.294-305, 1959.

NANDAVE, M.; OJHA, S. K.; JOSHI, S.; KUMARI, S.; ARYA, D. S. Cardioprotective effect Bacopa monneira against isoproterenol induced myocardial necrosis in rats. Int. $J$. Pharmacol., v.3, n.5, p.385-392, 2007.

NOGARDY, T. Medicinal chemistry-a biochemical approach. 2.ed. Oxford: University Press, 1998. p.239-241.

RANA, A. C.; SANTANI, D. D.; SALUJA, A. K. Pharmacological screening of the alcoholic extract of the leaves of Rubus ellipticus. Indian J. Pharm. Sci., v.52, n.4, p.174-177, 1990.

RAO, S. R.; AGARWAL, V. K. Effect of Bacopa monniera Linn on gastric ulceration and secretion. Indian J. Pharmacol., v.32, n.1, p.81, 2000.

RHO, J. M.; RAMAN, S. The pharmacologic basis of antiepileptic drug action. Epilepsia, v.40, n.1, p.1471-1483, 1999. 
SERTIA, J. A. A.; CAMARGO, E. A.; LUCIA, R. D.; PANIZZA, S. Pharmacology and toxicology of Centella asiatica extract. Fitoterapia, v.68, n.3, p.413-416, 1997.

SINGH, H. K.; DHAWAN, B. N. Neuropsycopharmacological effects of the ayurvedic nootropic Bacopa mooniera Linn. (Brahmi). Indian J. Pharmacol., v.29, n.5, p.359-365, 1997.

SUMATHI, T.; NONGBRI, A. Hepatoprotective effect of Bacoside-A, a major constituent of Bacopa mooniera Linn. Phytomedicine, v.15, n.10, p.901-905, 2008.
THE WEALTH OF INDIA. A Dictionary of Indian Raw Materials \& Industrial Products: Raw materials. New Delhi: CSIR, 1985. v.IA(revised), p.2.

VADILLO, F. J.; NOYA, M. Concept, classification and pathophysiology of status epilepticus Neuralgia, v.12, supl.6, p.2-9, 1997.

VIJI, V.; HELEN, A. Inhibition of lipoxygenases and cyclooxygenase-2 enzyme by extracts isolated from Bacopa monniera (L.) Wettst. J. Ethnopharmacol., v.118, n.2, p.305-311, 2008.

Received for publication on $11^{\text {th }}$ April 2008. Accepted for publication on $07^{\text {th }}$ April 2009. 
